\title{
Expression of $\beta$-catenin and REG I $\alpha$ in relation to cell proliferative ability in salivary gland tumors
}

\author{
YUKO HAKATA $^{1,2}$, HIROKAZU FUKUI ${ }^{1}$, AKIRA SEKIKAWA ${ }^{1}$, HIDETSUGU YAMAGISHI ${ }^{1}$, \\ KAZUHITO ICHIKAWA ${ }^{1}$, SHIGEKI TOMITA ${ }^{1}$, JOHJI IMURA ${ }^{1}$, HITOSHI KAWAMATA ${ }^{2}$, \\ YUTAKA IMAI $^{2}$ and TAKAHIRO FUJIMORI ${ }^{1}$ \\ Departments of ${ }^{1}$ Surgical and Molecular Pathology, and ${ }^{2}$ Oral Surgery, \\ Dokkyo University School of Medicine, Tochigi 321-0293, Japan \\ Received December 15, 2009; Accepted February 1, 2010
}

DOI: 10.3892/etm_00000068

\begin{abstract}
. $\beta$-catenin and its target gene products have been thought to play pivotal roles in the progression of various neoplasias. In the present study, we examined the expression of $\beta$-catenin and regenerating gene (REG) I $\alpha$ in salivary gland tumors and investigated its relationship to their cell proliferative ability. Nineteen patients with pleomorphic adenoma (PA) and 17 patients with malignant salivary gland tumors, including 7 adenoid cystic carcinomas, 7 mucoepidermoid carcinomas and 3 polymorphous low-grade adenocarcinomas, were enrolled. The specimens that had been surgically resected from these patients were examined using immunohistochemistry for $\beta$-catenin, REG I $\alpha$ and Ki67. The relationships between clinicopathological features and $\beta$-catenin or REG I $\alpha$ expression were then analyzed. $\beta$-catenin immunoreactivity was positive in 14 PAs (73.3\%) and 14 malignant salivary gland tumors $(82.4 \%)$. Four $(28.6 \%)$ of the $14 \beta$-catenin-positive PAs showed clear $\beta$-catenin immunoreactivity at the plasma membrane (membrane type), while 10 (71.4\%) showed diffuse immunoreactivity in the cytoplasm and nucleus but not at the plasma membrane (non-membrane type). Twelve $(85.9 \%)$ of the 14 malignant salivary gland tumors showed non-membrane-type $\beta$-catenin expression. Six $(31.6 \%)$ of the 19 PAs and $10(58.8 \%)$ of the 17 malignant salivary gland tumors were positive for REG I $\alpha$ expression. PAs with non-membrane-type $\beta$-catenin expression showed a significantly higher Ki67 labeling index than PAs with negative or membrane-type expression. Additionally, PAs that were REG I $\alpha$-positive showed a significantly higher Ki67 labeling index than those that were negative. Non-membranetype $\beta$-catenin expression was related to REG I $\alpha$ positivity in PA lesions. $\beta$-catenin and its associated REG I $\alpha$ protein may
\end{abstract}

Correspondence to: Dr Hirokazu Fukui, Department of Surgical and Molecular Pathology, Dokkyo University School of Medicine, 880 Kitakobayashi, Mibu, Shimotsuga, Tochigi 321-0293, Japan

E-mail: h-fukui@dokkyomed.ac.jp

Key words: $\beta$-catenin, regenerating gene I $\alpha$, salivary gland tumor play a role as growth-promoting factors in the development of salivary gland tumors.

\section{Introduction}

Salivary gland tumors present a wide spectrum of histological and pathophysiological features $(1,2)$. The most frequently occurring salivary gland tumor is pleomorphic adenoma (PA), which consists of epithelial and myoepithelial cell components and is basically benign, but can progress to a malignant neoplasm on rare occasions $(2,3)$. On the other hand, among malignant salivary gland tumors, adenoid cystic carcinoma (ACC) and mucoepidermoid carcinoma (MEC) are the most predominant (4), and their incidence is gradually increasing (5). However, the pathophysiology of salivary gland tumors is not well understood because of the variety of histopathological phenotypes and the paucity of previous molecular studies.

$\beta$-catenin, the abnormality of which is significantly associated with the growth, invasion and metastasis of various malignancies, very likely plays an important pathophysiological role in salivary gland tumors (6-10). Interestingly, a few immunohistochemical studies have revealed aberrant expression of $\beta$-catenin in the cytoplasm and/or nuclei of salivary gland tumor cells (7-10). Although the biological significance of aberrant $\beta$-catenin expression remains unclear, the alteration of $\beta$-catenin and its target genes has been shown to trigger the proliferation of salivary gland epithelial cells in mouse models (11-13). Therefore, it is tempting to speculate that aberrant $\beta$-catenin expression may be associated with cell proliferation in salivary gland tumors.

The regenerating gene (REG) I $\alpha$ protein, the human homologue of rat Reg protein, which was originally isolated from regenerating pancreatic islets (14), has been shown to play roles, not only in normal tissue regeneration $(15,16)$, but also in the development of various malignancies (17-20). We previously clarified that REG I $\alpha$ protein is involved in the regeneration of gastrointestinal epithelium (21) and also in the development of its associated cancer by promoting cell growth and/or anti-apoptosis (22-24). It was recently suggested that an abnormality in $\beta$-catenin may be associated with the overexpression of REG family proteins in liver tumors $(25,26)$. On the other hand, it is noteworthy that REG I $\alpha$ protein 
Table I. Relationship between clinicopathological features and $\beta$-catenin expression in patients with pleomorphic adenoma.

\begin{tabular}{|c|c|c|c|c|}
\hline \multirow[t]{2}{*}{ Clinicopathological features } & \multirow[t]{2}{*}{ No. of patients } & \multicolumn{2}{|c|}{$\beta$-catenin expression } & \multirow[t]{2}{*}{ P-value } \\
\hline & & Negative $(\mathrm{n}=5)$ & Positive ( $\mathrm{n}=14$ ) & \\
\hline Gender & & & & NS \\
\hline Male & 8 & $3(37.5)$ & $5(62.5)$ & \\
\hline Female & 11 & $2(18.2)$ & $9(81.8)$ & \\
\hline Age & $44.2 \pm 3.5$ & $44.0 \pm 9.8$ & $44.3 \pm 3.6$ & NS \\
\hline Tumor location & & & & NS \\
\hline Palate & 9 & $2(22.2)$ & $7 \quad(77.8)$ & \\
\hline Parotid & 3 & $1(33.3)$ & $2(66.7)$ & \\
\hline Submandibular & 3 & $1(33.3)$ & $2(66.7)$ & \\
\hline Oral mucosa & 3 & $1(33.3)$ & $2(66.7)$ & \\
\hline Minor salivary gland & 1 & $\begin{array}{ll}0 & (0.0)\end{array}$ & $1(100.0)$ & \\
\hline Stage & & & & NS \\
\hline I & 7 & $2(28.6)$ & $5 \quad(71.4)$ & \\
\hline II & 10 & $3(30.0)$ & $7 \quad(70.0)$ & \\
\hline III & 2 & $0 \quad(0.0)$ & $2(100.0)$ & \\
\hline Tumor size & $33.2 \pm 9.6$ & $24.6 \pm 4.7$ & $36.2 \pm 13.0$ & NS \\
\hline
\end{tabular}

plays a role in the regeneration of minor salivary glands (27) suggesting possible involvement of REG I $\alpha$ protein in the development of salivary gland tumors. Thus, in the present study, we investigated the expression of REG I $\alpha$ and $\beta$-catenin in salivary gland tumors, focusing on the possible linkage of their expressional profiles and their relationship to tumor proliferative ability.

\section{Materials and methods}

Patients, tissue samples and histology. Nineteen patients with PAs ( 8 males, 11 females; mean age 44.2 years, range 14-70 years) and 17 patients with malignant salivary tumors [7 males, 10 females; mean age 56.8 years, range $23-85$ years; 7 ACCs, 7 MECs, 3 polymorphous low-grade adenocarcinomas (PLGAs)] who were diagnosed and treated at Dokkyo University School of Medicine between 1994 and 2007 were enrolled. Samples of salivary gland tissue were obtained by surgery from patients with salivary gland tumors. Tissue specimens were fixed in $10 \%$ neutral buffered formalin and embedded in paraffin. Multiple H\&E-stained sections of each sample were examined histologically. This study was conducted with the approval of the Dokkyo University Surgical Pathology Committee, and informed consent was obtained from all patients.

Immunohistochemistry. Immunohistochemical staining for REG I $\alpha$, $\beta$-catenin and Ki67 was performed with a LSAB-2 kit (Dako, Marseille, France) as described previously (17). In brief, 4- $\mu \mathrm{m}$ sections were placed on slides, deparaffinized and dehydrated. They were then placed in $0.01 \mathrm{~mol} / 1$ citrate buffer ( $\mathrm{pH}$ 6.0) and treated by microwave heating $(400 \mathrm{~W}$, $95^{\circ} \mathrm{C}$; MI-77; Azumaya, Tokyo, Japan) for $40 \mathrm{~min}$ to facilitate antigen retrieval. This was followed by pretreatment with $0.3 \%$ $\mathrm{H}_{2} \mathrm{O}_{2}$ in methanol for $20 \mathrm{~min}$ at room temperature to quench endogenous peroxidase activity. The sections were incubated with $1 \%$ bovine serum albumin in phosphate-buffered saline (PBS) for $30 \mathrm{~min}$, and then with anti-REG I $\alpha$ (dilution 1:100), anti- $\beta$-catenin (BD Transduction Laboratories, CA, USA; dilution 1:500) and anti-Ki67 (Dako Japan, Kyoto, Japan; dilution 1:50) for $1 \mathrm{~h}$. Thereafter, the sections were incubated with biotinylated secondary antibody for $15 \mathrm{~min}$, washed with PBS and treated with peroxidase-conjugated streptavidin for $20 \mathrm{~min}$. Finally, the sections were incubated in 3,3'-diaminobenzidine tetrahydrochloride with $0.05 \% \mathrm{H}_{2} \mathrm{O}_{2}$ for 3 min and then counterstained with Mayer's hematoxylin.

Evaluation of immunohistochemical staining. The immunoreactivity of REG I $\alpha$ was observed in the cytoplasm of salivary gland tumor cells. At least 500 tumor cells were observed in five different visual fields for each tissue sample. A specimen was considered positive for REG I $\alpha$ protein when $\geq 10 \%$ of the tumor cells were positively stained; otherwise, the specimens were considered negative (28).

Similarly, a specimen was considered positive for $\beta$-catenin when $\geq 10 \%$ of the tumor cells were positively stained; otherwise, the specimens were considered negative (9). Regarding the expression pattern of $\beta$-catenin, some salivary gland tumors showed clear $\beta$-catenin immunoreactivity at the plasma membrane and a weak signal in the cytoplasm (membrane type), while others showed immunoreactivity in the cytoplasm diffusely and in the nuclei clearly but not at the plasma membrane (non-membrane type).

Ki67 was used as a marker for measures of cell proliferation (29). The immunoreactivity of Ki67 in tumor nuclei was assessed as described above. The Ki67 labeling index was 
Table II. Clinicopathological features and expression of REG I $\alpha$ and $\beta$-catenin in patients with malignant salivary gland tumors.

\begin{tabular}{|c|c|c|c|c|c|c|}
\hline Case & Histology & Age & Gender & T stage & REG I $\alpha$ expression & $\beta$-catenin expression \\
\hline 1 & $\mathrm{ACC}$ & 65 & M & $\mathrm{T} 4$ & + & Non-membrane \\
\hline 2 & $\mathrm{ACC}$ & 72 & $\mathrm{~F}$ & $\mathrm{~T} 2$ & + & Non-membrane \\
\hline 3 & $\mathrm{ACC}$ & 70 & M & $\mathrm{T} 1$ & + & Non-membrane \\
\hline 4 & $\mathrm{ACC}$ & 25 & M & $\mathrm{T} 1$ & + & Membrane \\
\hline 5 & $\mathrm{ACC}$ & 23 & $\mathrm{~F}$ & $\mathrm{~T} 2$ & - & Non-membrane \\
\hline 6 & $\mathrm{ACC}$ & 75 & M & $\mathrm{T} 1$ & - & Non-membrane \\
\hline 7 & $\mathrm{ACC}$ & 67 & $\mathrm{~F}$ & $\mathrm{~T} 2$ & - & - \\
\hline 8 & MEC & 59 & M & $\mathrm{T} 2$ & + & Non-membrane \\
\hline 9 & MEC & 27 & $\mathrm{~F}$ & $\mathrm{~T} 2$ & + & Non-membrane \\
\hline 10 & MEC & 47 & $\mathrm{~F}$ & $\mathrm{~T} 2$ & + & Non-membrane \\
\hline 11 & MEC & 57 & $\mathrm{~F}$ & $\mathrm{~T} 2$ & + & Non-membrane \\
\hline 12 & MEC & 68 & $\mathrm{~F}$ & $\mathrm{~T} 2$ & + & Non-membrane \\
\hline 13 & MEC & 26 & $\mathrm{~F}$ & $\mathrm{~T} 2$ & - & Non-membrane \\
\hline 14 & MEC & 85 & M & $\mathrm{T} 1$ & - & Membrane \\
\hline 15 & PLGA & 72 & $\mathrm{~F}$ & $\mathrm{~T} 2$ & + & Non-membrane \\
\hline 16 & PLGA & 65 & M & $\mathrm{T} 2$ & - & - \\
\hline 17 & PLGA & 63 & $\mathrm{~F}$ & $\mathrm{~T} 1$ & - & - \\
\hline
\end{tabular}

ACC, adenoid cystic carcinoma; MEC, mucoepidermoid carcinoma; PLGA, polymorphous low-grade adenocarcinoma; M, male; F, female. REG I $\alpha$ expression: -, negative; +, positive. $\beta$-catenin expression: -, negative.

calculated as the percentage of positive cell nuclei in each sample.

Statistical analysis. Chi-square analyses were performed to investigate the relationship between various clinicopathological parameters, and the Fisher's exact test was also used, as necessary. Ki67 labeling index, age and tumor size were expressed as the mean \pm SEM, and the significance of differences between two groups was assessed using the MannWhitney U-test. Differences at $\mathrm{P}<0.05$ were considered to be significant.

\section{Results}

Clinicopathological features of salivary gland tumors. The results of the clinicopathological analyses of PAs and malignant salivary gland tumors are summarized in Tables I and II, respectively.

Nineteen PAs were obtained from 19 patients $(8$ males and 11 females) with a mean age of 44.2 years. The lesions were located in the palate $(n=9 ; 47.3 \%)$, parotid $(n=3 ; 15.8 \%)$, submandibular $(n=3 ; 15.8 \%)$, oral mucosa $(n=3 ; 15.8 \%)$ and

Figure 1. Immunostaining of $\beta$-catenin and REG I $\alpha$ in PA (A and B), ACC (C and D), MEC (E and F) and PLGA (G and H). (A) Left panel shows membrane-type $\beta$-catenin expression. Immunoreactivity for $\beta$-catenin is detected at the plasma membrane of tumor cells clearly and in the cytoplasm weakly. Right panel shows non-membrane-type expression. The immunoreactivity is detected in the cytoplasm of tumor cells diffusely and in the nuclei clearly. (B) Immunoreactivity for REG I $\alpha$ protein is detected in the cytoplasm of PA cells. (C, E and G) Non-membrane-type $\beta$-catenin expression in ACC, MEC and PLGA, respectively. (D, F and $\mathrm{H}$ ) Expression of REG I $\alpha$ protein in ACC, MEC and PLGA, respectively. Scale bars, $100 \mu \mathrm{m}$.

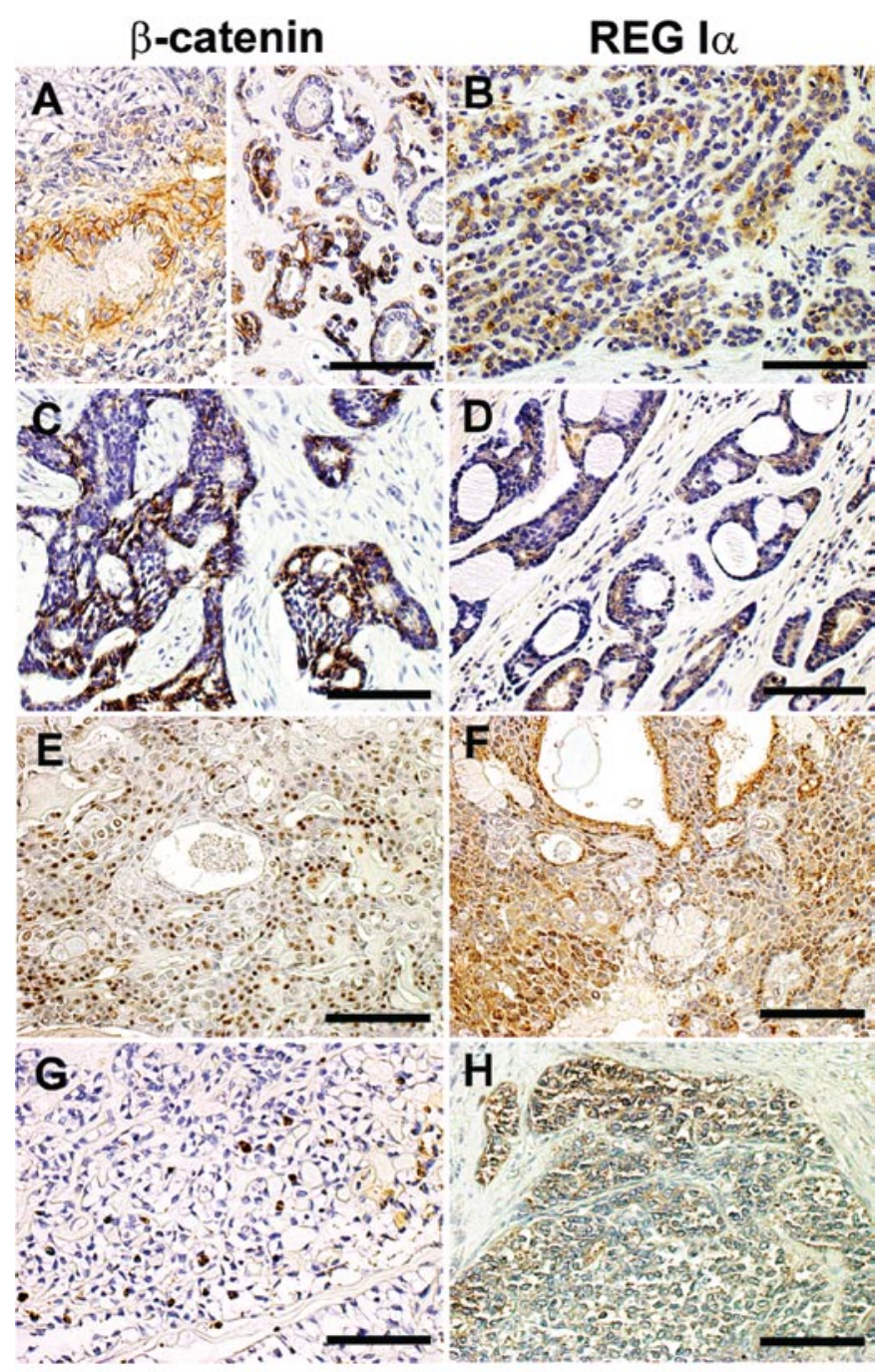


Table III. Relationship between clinicopathological features and $\beta$-catenin expression pattern in patients with pleomorphic adenoma.

\begin{tabular}{lccc}
\hline & \multicolumn{2}{c}{$\beta$-catenin expression pattern } & \\
\cline { 2 - 4 } Clinicopathological features & Non-membrane $(\mathrm{n}=10)$ & Membrane $(\mathrm{n}=4)$ & NS \\
\hline Gender & 3 & 2 & \\
Male & 7 & 2 & NS \\
Female & $44.1 \pm 5.1$ & $44.8 \pm 1.6$ & NS \\
Age & & & \\
Tumor location & 6 & 1 & 0.030 \\
Palate & 1 & 1 & \\
Parotid & 1 & 1 & \\
Submandibular & 1 & 0 & \\
Oral mucosa & 1 & 0 & \\
$\quad$ Minor salivary gland & & 2 & \\
Stage & 5 & 2 & \\
I & 5 & $77.8 \pm 40.9$ & \\
II & 0 & 1 & \\
III & $19.6 \pm 3.1$ & & \\
Tumor size & & & \\
\hline
\end{tabular}

NS, not significant.

minor salivary gland $(\mathrm{n}=1 ; 5.3 \%)$. The size of the tumors ranged from 9 to $200 \mathrm{~mm}$, with a mean of $33.2 \mathrm{~mm}$ (Table I).

Among the malignant salivary gland tumors, 7 ACCs, 7 MECs and 3 PLGAs were analyzed as presented in Table II.

Relationship between clinicopathological features and $\beta$-catenin expression in salivary gland tumors. Representative immunostaining patterns of $\beta$-catenin in salivary gland tumors are shown in Fig. 1. Among the PAs, 14 (73.3\%) of the 19 lesions were positive for $\beta$-catenin expression. None of the parameters examined, including gender, age, tumor location, stage or tumor size, had a significant relationship to $\beta$-catenin positivity. Among the malignant salivary gland tumors, 6 $(85.7 \%)$ of the 7 ACCs, all (100\%) 7 MECs and 1 (33.3\%) of the 3 PLGAs were positive for $\beta$-catenin expression (Table II).

Regarding the expression pattern of $\beta$-catenin, 4 (28.6\%) of the $14 \beta$-catenin-positive PAs showed clear $\beta$-catenin immunoreactivity at the plasma membrane (membrane type), while 10 (71.4\%) showed diffuse immunoreactivity in the cytoplasm and nucleus, but not at the plasma membrane (non-membrane type) (Table III). PAs showing a non-membrane-type $\beta$-catenin immunostaining pattern were significantly early-stage and small in size compared to the PAs showing membrane-type immunostaining (Table III). However, a non-membrane-type $\beta$-catenin immunostaining pattern was frequently observed in $12(85.7 \%)$ of the 14 malignant salivary gland tumors (Table II).

Relationship between clinicopathological features and REG I $\alpha$ expression in salivary gland tumors. REG I $\alpha$ protein immunoreactivity was detected in the cytoplasm of tumor
A

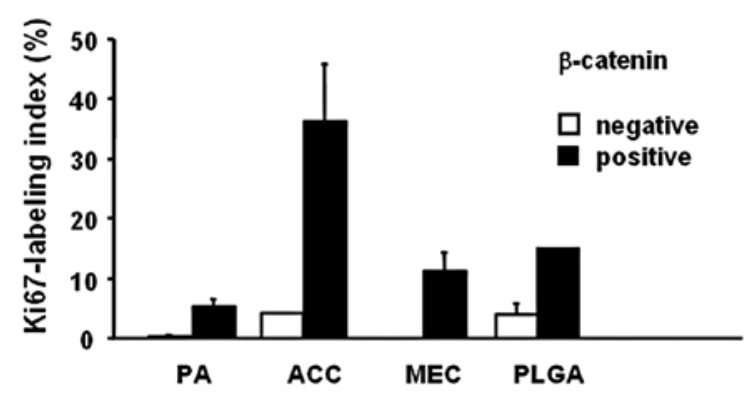

B
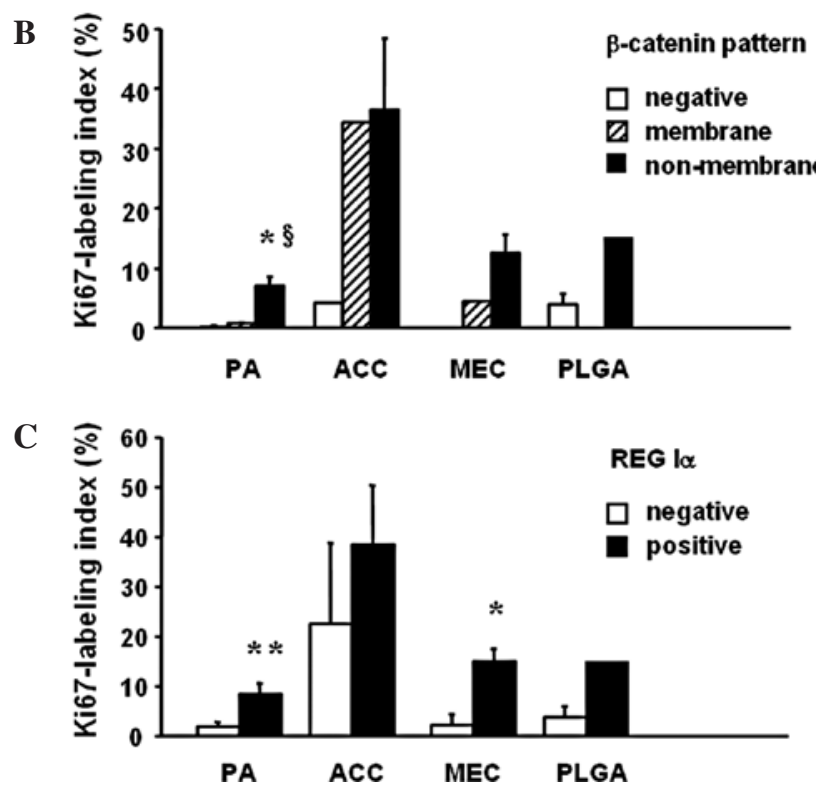

Figure 2. Relationship between the Ki67 labeling index and $\beta$-catenin expression (A), $\beta$-catenin expression pattern (B) or REG I $\alpha$ expression (C) in salivary gland tumors. All results are expressed as the mean \pm SEM. ${ }^{*} \mathrm{P}<0.05$, ${ }^{* *} \mathrm{P}<0.005$ vs. negative group; ${ }^{\circledR} \mathrm{P}<0.05$ vs. membrane group. 
Table IV. Relationship between clinicopathological features and REG I $\alpha$ expression in patients with pleomorphic adenoma.

\begin{tabular}{|c|c|c|c|}
\hline \multirow[t]{2}{*}{ Clinicopathological features } & \multicolumn{2}{|c|}{ REG I $\alpha$ expression } & \multirow[t]{2}{*}{ P-value } \\
\hline & Negative $(n=13)$ & Positive $(n=6)$ & \\
\hline Gender & & & NS \\
\hline Male & $5(62.5)$ & $3(37.5)$ & \\
\hline Female & $8(72.7)$ & $3(27.3)$ & \\
\hline Age & $45.5 \pm 4.3$ & $41.3 \pm 6.6$ & NS \\
\hline Tumor location & & & NS \\
\hline Palate & $5 \quad(55.6)$ & $4 \quad(44.4)$ & \\
\hline Parotid & $2(66.7)$ & $1 \quad(33.3)$ & \\
\hline Submandibular & $3(100.0)$ & $0 \quad(0.0)$ & \\
\hline Oral mucosa & $3(100.0)$ & $0 \quad(0.0)$ & \\
\hline Minor salivary gland & $0 \quad(0.0)$ & $1(100.0)$ & \\
\hline Stage & & & NS \\
\hline I & $4(57.1)$ & $3(42.9)$ & \\
\hline II & $7(70.0)$ & $3(30.0)$ & \\
\hline III & $2(100.0)$ & $0 \quad(0.0)$ & \\
\hline Tumor size & $40.0 \pm 13.7$ & $18.3 \pm 3.1$ & NS \\
\hline
\end{tabular}

NS, not significant.

Table V. Correlation between REG I $\alpha$ and the $\beta$-catenin expression pattern in patients with pleomorphic adenoma.

\begin{tabular}{lcrc}
\hline Clinicopathological features & $\beta$-catenin-negative $(\mathrm{n}=5)$ & \multicolumn{2}{c}{$\beta$-catenin-positive $(\mathrm{n}=14)$} \\
\cline { 3 - 4 } & & Membrane & Non-membrane \\
\hline REG I $\alpha$ expression & $5(38.5)$ & 4 & 4 \\
Negative & $0(0.0)$ & 0 & $6^{\mathrm{a}}$ \\
Positive & & $6(100.0)$ \\
\hline
\end{tabular}

aPleomorphic adenomas showing non-membrane-type $\beta$-catenin expression were significantly positive for REG I $\alpha$ expression (P=0.040).

cells. As shown in Fig. 2, REG I $\alpha$ immunoreactivity was detected in salivary gland tumors of various types and stages.

Six $(31.6 \%)$ of the 19 PAs were positive for REG I $\alpha$ protein. Gender, age, tumor location, stage or tumor size did not have any significant relationship to REG I $\alpha$ protein expression in PAs (Table IV).

Among the malignant salivary gland tumors, REG I $\alpha$ protein expression was positive in $4(57.1 \%)$ of the 7 ACCs, $5(71.4 \%)$ of the 7 MECs and $1(33.3 \%)$ of the 3 PLGAs (Table II). REG I $\alpha$ positivity tended to be higher in malignant salivary gland tumors than in PAs (31.6 vs. $58.8 \%, \mathrm{P}=0.099)$.

Relationship between Ki67 labeling index and $\beta$-catenin or REG I $\alpha$ expression in salivary gland tumors. We next examined the relationship between cell proliferative ability and $\beta$-catenin or REG I $\alpha$ expression in salivary gland tumors. PAs that were positive for $\beta$-catenin showed a higher Ki67 labeling index than those that were negative $(\mathrm{P}=0.069$, Fig. 2A). In addition, PAs with non-membrane-type $\beta$-catenin expression showed a significantly higher Ki67 labeling index than PAs with negative or membrane-type expression (Fig. 2B). Furthermore, PAs that were positive for REG I $\alpha$ showed a significantly higher Ki67 labeling index than those that were negative (Fig. 2C). Similar findings were obtained in malignant salivary gland tumors, although the data are preliminary due to the small number of samples examined.

Correlation between $\beta$-catenin and REG I $\alpha$ expression in salivary gland tumors. REG I $\alpha$-positive PAs tended to be positive for $\beta$-catenin (Table $\mathrm{V} ; \mathrm{P}=0.078$ ), and PAs with non-membrane-type $\beta$-catenin expression were significantly positive for REG I $\alpha$ (Table V).

\section{Discussion}

Human salivary gland tumors are a histologically heterogeneous group, and their progression is thought to be a multi-step process that results in the acquisition of cell proliferative 
ability $(1,2)$. In the present study, we showed that $\beta$-catenin expression was associated with the cell proliferative ability of PA lesions. Additionally, we observed aberrant expression of $\beta$-catenin in the cytoplasm and/or nuclei of cells in various salivary gland tumors, compatible with previous reports (7-10). Recently, a variety of tumor cells has been reported to show aberrant expression and/or loss of membranous $\beta$-catenin expression (30), although its biological significance is not fully clear. Notably, in this study we found that PAs with aberrant $\beta$-catenin expression had a higher proliferative potential than those with membrane-type $\beta$-catenin expression, suggesting that aberrant $\beta$-catenin expression may reflect the acquisition of tumor growth ability. In this regard, it appears reasonable that the frequency of aberrant $\beta$-catenin expression was higher in malignant salivary gland tumors than in PAs. At present we are unable to explain the precise intracellular mechanism responsible for the translocation of $\beta$-catenin; however, accumulating evidence suggests that translocated $\beta$-catenin acts as a transcriptional factor for oncogenic or growth-associated genes in the cells of several cancer types (31). Therefore, it is tempting to speculate that aberrant $\beta$-catenin expression may be associated with the overexpression of such genes in salivary gland tumors as well.

Additionally, in the present study we showed that REG I $\alpha$ was overexpressed in a considerable number of PAs and other malignant salivary gland tumors. Similarly, recent studies have reported that REG $\mathrm{I} \alpha$ is overexpressed, not only in gastroenterological cancers $(17,18,23)$, but also in lung cancer (19) and seminoma (20), suggesting that REG I $\alpha$ protein plays a role in the pathogenesis of various malignancies. In fact, we and others previously clarified that REG I $\alpha$ protein functions as a cell growth and/or anti-apoptotic factor by activating the MAKP or Akt pathway in gastric or colon cancer cells $(23,24,32)$. In this context, we examined the relationship between REG I $\alpha$ expression and cell proliferative ability in salivary gland tumors and found that PAs expressing REG I $\alpha$ showed a significantly higher cell proliferation index than those that were negative, and moreover that the rate of REG I $\alpha$ positivity was apparently higher in malignant salivary gland tumors. Thus, as in other tumors, REG I $\alpha$ protein may act as a growth factor in the pathogenesis of salivary gland tumors.

We also investigated the relationships among clinicopathological features and the expression of REG $\mathrm{I} \alpha$ and $\beta$-catenin in PAs. We initially expected that PAs with nonmembrane-type $\beta$-catenin expression would be at a later stage and larger in size, since such PAs showed higher proliferation ability; however, the data we obtained suggested the contrary. Similarly, REG I $\alpha$-positive PAs tended to be early-stage tumors that were small in size. At present, we have no satisfactory explanation for these findings since the number of tumor samples examined, especially those at a late stage, was small. However, it is evident that both $\beta$-catenin and REG I $\alpha$ play roles from the early phase of progression of PA lesions. On the other hand, it is noteworthy that REG I $\alpha$-positive PAs showed a significantly higher incidence of non-membranetype $\beta$-catenin expression. Cavard et al recently suggested that the REG I $\alpha$ gene is a downstream target of Wnt/ $\beta$-catenin signaling in hepatocellular carcinoma cells (25). This may support the positive relationship between aberrant $\beta$-catenin expression and REG I $\alpha$ positivity in PA lesions.
In summary, we observed that immunoreactivity for $\beta$-catenin was detectable, not only in the plasma membrane, but also in the cytoplasm or nucleus of cells in various salivary gland tumors. In addition, REG I $\alpha$ protein was expressed in a considerable number of PAs and other malignant salivary gland tumors. Furthermore, we showed that both $\beta$-catenin and REG I $\alpha$ are significantly associated with the proliferative ability of PA lesions and that aberrant $\beta$-catenin expression was related to REG I $\alpha$ positivity in such lesions. Taken together, our findings suggest that $\beta$-catenin and its candidate target REG I $\alpha$ may act as growth-promoting factors in the development of salivary gland tumors.

\section{Acknowledgements}

The authors thank Chiaki Matsuyama, Ayako Shimizu, Takako Ono, Midori Katayama, Atsuko Kikuchi and Sachiko Miyahara (Department of Surgical and Molecular Pathology, Dokkyo University School of Medicine, Tochigi, Japan) for the excellent technical and secretarial assistance. We are grateful to Dr Hiroshi Okamoto from the Tohoku University Graduate School of Medicine, Sendai, Japan, for providing the anti-REG I $\alpha$ antibody. This study was supported, in part, by Grants-in-aid for Scientific Research 20590747 from the Ministry of Education, Culture, Sports, Science and Technology of Japan.

\section{References}

1. Eveson JW and Cawson RA: Salivary gland tumours: a review of 2410 cases with particular reference to histological types, site, age and sex distribution. J Pathol 146: 51-58, 1985.

2. Cheuk W and Chan JKC: Advances in salivary gland pathology. Histopathology 51: 1-20, 2007.

3. Altemani A, Martins MT, Fretias L, Soares F, Araujo NS and Araujo VC: Carcinoma ex-pleomorphic adenoma (CXPA): immunoprofile of the cells involved in carcinomatous progression. Histopathology 46: 635-641, 2005.

4. Speight PM and Barrett AW: Salivary gland tumours. Oral Dis 8: 229-240, 2002.

5. Carvalho AL, Nishimoto IN, Califano JA and Kowalski LP: Trends in incidence and prognosis for head and neck cancer in the United States: a site-specific analysis of the SEER database. Int J Cancer 114: 806-816, 2005.

6. Shibuya Y, Ri S, Umeda M, Yoshikawa T, Masago H and Komori T: Ultrastructural localization of E-cadherin and $\alpha$-/ $\beta$-catenin in adenoid cystic carcinoma. Histopathology 35: 423-431, 1999.

7. Prado RF, Consolaro A and Taveira LAA: Expression of $\beta$-catenin in carcinoma in pleomorphic adenoma, pleomorphic adenoma and normal salivary gland: immunohistochemical study. Oral Med Pathol 11: E247-E251, 2006.

8. Furuse C, Cury PR, Altemani A, dos Santos Pinto D Jr, de Araújo NS and de Araújo VC: $\beta$-catenin and E-cadherin expression in salivary gland tumors. Int J Sur Pathol 14: 212-217, 2006.

9. Genelhu MC, Gobbi H, Arantes DC, Cardoso SV and Cassali D Immunolocalization of $\beta$-catenin in pleomorphic adenomas and carcinomas ex-pleomorphic adenomas of salivary glands. Appl Immunohistochem Mol Morphol 15: 273-278, 2007.

10. Ferrazzo KL, Neto MM, dos Santos E, dos Santos Pinto D and de Sousa SO: Differential expression of galectin-3, $\beta$-catenin and cyclin D1 in adenoid cystic carcinoma and polymorphous low-grade adenocarcinoma of salivary glands. J Oral Pathol Med 38: 701-707, 2009.

11. Tsukamoto AS, Grosschedl R, Guzman RC Parslow T and Varmus HE: Expression of the int-1 gene in transgenic mice is associated with mammary gland hyperplasia and adenocarcinoma in male and female mice. Cell 55: 619-625, 1988.

12. Roose J, Huls G, van Beest M, et al: Synergy between tumor suppressor APC and the beta-catenin-Tcf4 target Tcf1. Science 285: 1923-1926, 1999. 
13. Stepanova L, Finegold M, DeMayo F, Schmidt EV and Harper JW: The oncoprotein kinase chaperone CDC37 functions as an oncogene in mice and collaborates with both c-myc and cyclin D1 in transformation of multiple tissues. Mol Cell Biol 20: 4462-4473, 2000.

14. Terazono K, Yamamoto $\mathrm{H}$, Takasawa S, et al: A novel gene activated in regenerating islets. J Biol Chem 263: 2111-2114, 1988.

15. Watanabe T, Yonekura $H$, Terazono $K$, Yamamoto $H$ and Okamoto H: Complete nucleotide sequence of human reg gene and its expression in normal and tumoral tissues. J Biol Chem 265: 7432-7439, 1990.

16. Asahara M, Mushiake S, Shimada S, et al: Reg gene expression is increased in rat gastric enterochromaffin-like cells following water immersion stress. Gastroenterology 111: 45-55, 1996.

17. Fukui H, Fujii S, Takeda J, et al: Expression of Reg I $\alpha$ in human gastric cancers. Digestion 69: 177-184, 2004.

18. Astrosini C, Roeefzaad C, Dai YY, Dieckgraefe BK, Jöns T and Kemmner W: REGIA expression is a prognostic marker in colorectal cancer and associated with peritoneal carcinomatosis. Int J Cancer 123: 409-413, 2008.

19. Minamiya $\mathrm{Y}$, Kawai H, Saito $\mathrm{H}$, et al: REG1A expression is an independent factor predictive of poor prognosis in patients with non-small cell lung cancer. Lung Cancer 60: 98-104, 2008.

20. Mauro V, Carette D, Chevallier D, et al: Reg I protein in healthy and seminoma human testis. Histol Histopathol 23: 1195-1203, 2008.

21. Fukui H, Franceschi F, Penland RL, et al: Effects of Helicobacter pylori infection on the link between regenerating gene expression and serum gastrin levels in Mongolian gerbils. Lab Invest 83: 1777-1786, 2003.

22. Fukui H, Kinoshita Y, Maekawa T, et al: Regenerating gene protein may mediate gastric mucosal proliferation induced by hypergastrinemia in rats. Gastroenterology 115: 1483-1493, 1998.

23. Sekikawa A, Fukui H, Fujii S, et al: REG I $\alpha$ protein may function as a trophic and/or anti-apoptotic factor in the development of gastric cancer. Gastroenterology 128: 642-653, 2005.
24. Sekikawa A, Fukui H, Fujii S, et al: Possible role of REG Ia protein in ulcerative colitis and colitic cancer. Gut 54: 1437-1444, 2005.

25. Cavard C, Terris B, Grimber G, et al: Overexpression of regenerating islet-derived 1 alpha and 3 alpha genes in human primary liver tumors with beta-catenin mutations. Oncogene 25: 599-608, 2006.

26. Yuan RH, Jeng YM, Chen HL, et al: Opposite roles of human pancreatitis-associated protein and REG1A expression in hepatocellular carcinoma: association of pancreatitis-associated protein expression with low-stage hepatocellular carcinoma, beta-catenin mutation, and favorable prognosis. Clin Cancer Res 11: 2568-2575, 2005

27. Kimura T, Fukui H, Sekikawa A, et al: Involvement of REG Io protein in the regeneration of ductal epithelial cells in the minor salivary glands of patients with Sjögren's syndrome. Clin Exp Immunol 155: 16-20, 2009.

28. Sasahira T, Oue N, Kirita T, et al: Reg IV expression is associated with cell growth and prognosis of denoid cystic carcinoma in the salivary gland. Histopathology 53: 667-675, 2008.

29. Gerdes J, Li L, Schlueter C, et al: Immunohistochemical and molecular biologic characterization of the cell proliferation-associated nuclear antigen that is defined by monoclonal antibody Ki-67. Am J Pathol 138: 867-873, 1991.

30. Van Aken E, De Wever O and Correia da Rocha AS: Defective E-cadherin/catenin complexes in human cancer. Virchows Arch 439: 725-751, 2001.

31. Mosimann C, Hausmann G and Basler $\mathrm{K}$ : $\beta$-catenin hits chromatin: regulation of Wnt target gene activation. Nat Rev Mol Cell Biol 10: 276-286, 2009.

32. Kadowaki Y, Ishihara S, Miyaoka Y, et al: Reg protein is overexpressed in gastric cancer cells, where it activates a signal transduction pathway that converges on ERK1/2 to stimulate growth. FEBS Lett 530: 59-64, 2002. 